We hope that the publication of these exceptional findings will be followed by the study of the ascend. ants in other cases of 'primary macroglobulinæmia'.

Centre Hospitalier de Saint-Nazaire.

$$
\text { R. MASSARI }
$$

J. M. FIN

ine, Paris.

Centre des Macromolécules, Strasbourg.

\section{Hæmogram of Normal and Starved Rats}

THE bioassay of plasma erythropoietin by the starved rat method was introduced by Fried $e t$ al. in $1957^{1}$ and has since been utilized by other investigators for evaluating erythropoietic stimuli. Gross changes in peripheral blood are apparent in all rats prepared for assay by withdrawal of food for varying periods of time.

The hæmograms of Sprague-Dawley rats before and after starvation for $80-96 \mathrm{~h}$ are shown in Table 1 . The rats were kept singly in cages and had previously been fed on standard 'Purina' laboratory chow. Water ad lib. was provided during the starvation period. Pre-starvation body-weights were $155-170 \mathrm{~g}$; after starvation, weights ranged from 100 to $121 \mathrm{~g}$.

Mean levels of hæmoglobin, hæmatocrit and red blood cell count before starvation are comparable with other published values on 'normal' laboratory rats $^{2,3}$. The hypochromia and microcytosis of the erythrocytes may be indicative of relative irondeficiency, though iron $(3 \mathrm{mg} / 10 \mathrm{~g}$ food) was included in the rat diet. High red blood cell, platelet and reticulocyte counts are a striking feature of the normal rat hæmogram. The intense reticulocytosis in the Sprague-Dawley rats before starvation is higher than that noted in an early investigation of normal albino rats by Orten and Smith ${ }^{2}$. Their figures reveal a mean of about 8 per cent reticulocytes in rats of comparable size.

The polycythæmia and hæmoconcentration seen after starvation (Table 1) are probably a reflexion of the degree of dehydration in the starved animals. Similar changes occur in rats given food but no water.

Inanition was accompanied by leukopænia which varied in individual rats from 1,600 to 4,300 white blood cells per cubic millimetre of blood. Differential leukocyte counts were not averaged because of marked variation from one animal to another. Granulocytes were generally less than 20 per cent of peripheral whito cells in normal rats and no real differences were found in the starved animals.

Specific nutritional defieiencies known to influence hæmatopoiesis were not delineated in the starved rats. It seems possible, however, that part of the response of the starved rats to anæmic plasma, and indeed the slight erythropoietic effect of normal plasma or saline, may be the result of factors other than a specific hormonal erythropoietic factor. The suggestion has been made that polycythæmia plasma contains an inhibitor to exythropoiesis ${ }^{4}$. Any such inhibition is apparently easily overcome by anæmic plasmn and even to some oxtent by normal plasma or

Table 1. MFan Hematological ValURS IN 88 SpRagUe-DaWley RATS BEFORE AND AFTER STARVATION

Body-weight (g)
Hrmoglobin (g/100 ml.)
Hrmatocrit (\%)
R.B.C. (million $\left./ \mathrm{mm}^{3}\right)$
F eticulocytes $(\%$ of R.B.C.)
W.B.C. (per mm $\mathrm{m}^{3}$ )
Platelets (direct count $/ \mathrm{mm}^{\mathrm{s}}$ )

$\begin{array}{cc}\text { Before starvation } & \text { After starvation } \\ 155-170 & 100-121 \\ 12 \cdot 8 & 17 \cdot 9 \\ 46 & 58 \\ 6 \cdot 86 & 9 \cdot 18 \\ 19 & 0 \cdot 8 \\ 19,400 & 3,680 \\ 934,000 & 669,000\end{array}$

saline. Reticulocytes in the starved rats increased from a mean of 0.8 per cent on the fourth day of starvation to 3.0 per cent $24 \mathrm{~h}$ after normal saline $(3.0 \mathrm{ml}$.) alone was given intravenously.

\section{JEANETTE SCHULZ}

Department of Pediatrics,

School of Medicine,

University of California at Los Angeles.

${ }^{1}$ Fried, W., Plzak, L. F., Jacobson, L. O., and Goldwasser, E., Proc. Soe. Exp. Biol. Med., 94, 237 (1957).

${ }^{2}$ Orten, J. M., and Smith, A. H., Amer. J. Physiol., 108, 66 (1934).

${ }^{3}$ Wintrobe, M. M., Clinical Hematology (Lea and Febiger, 1961).

${ }^{4}$ Krzmowski, T., and Krzmowska, H., Blood, 19, 38 (1962).

\section{PATHOLOGY}

\section{Pathological Proliferation of the Tropho- blast Homograft in Women}

Aвошт $1 \mathrm{~g}$ of trophoblast tissue, obtained in the course of legal interruptions in the second and third month of pregnancy, was grafted into the abdominal wall (mm. recti abd.) of: (a) 5 elderly women suffering from incurable cervical cancer; (b) 25 elderly womon suffering from incurable cervical cancer and trcated daily with $5 \mathrm{mg}$ of cestrone acetate 3 weeks prior to grafting and consecutively until the removal of the graft; (c) 3 patients suffering from endogenous hyperœstrogenism.

5-7 weeks later the grafts were removed and examinod histologically, about one half of the tissue being reserved for the estimation of chorionic gonadotropin (HCG).

The grafts from the cancer patients not treated with cestrogens were found, according to expectation, to have degenerated (Fig. 1), and no HCG could be detected by the Galli Mainini test. The grafts from œstrogen-treated patients showed no homograft reaction, were viable, and in addition marked proliferation with polymorphism of the nucloi and metachromasia were also present (Fig. 2). In some instances syncytial cells were found dispersed in the connective tissue (Fig. 3). Similar findings were obtained in cases suffering from endogenous hyperœstrogenism (Fig. 4).

The results demonstrate clearly that a high œestrogen-level suppresses the reaction of the host to homologous trophoblast tissue, and permits this not only to proliferate but also to synthesize HCG. It remains to be seen whether this action of cestrogen

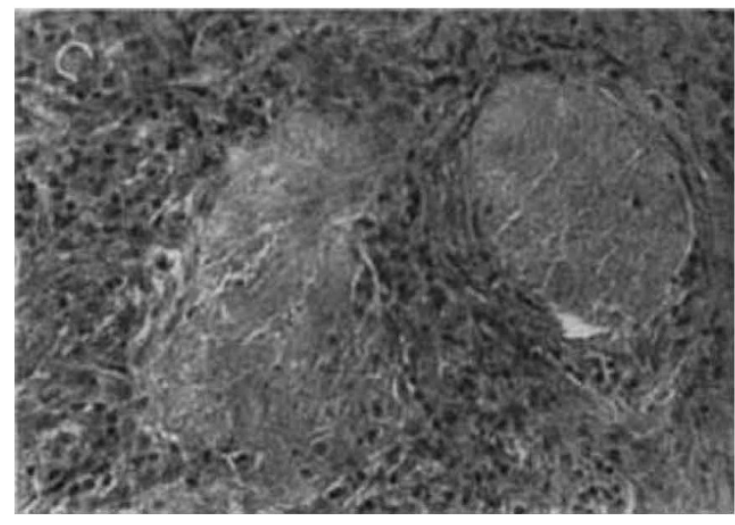

Fig. 1. Trophoblast implanied without cestrogen treatment. Degenerated villi, inflammatory infiltration. (Hæmatoxylin-osin 